\title{
Adjuvant-dependent regulation of interleukin-17 expressing $\gamma \delta$ T cells and inhibition of Th2 responses in allergic airways disease
}

\author{
Emily M Nakada, Jichuan Shan, Margaret W Kinyanjui and Elizabeth D Fixman*
}

\begin{abstract}
Background: Th2 immune responses are linked primarily to mild and moderate asthma, while Th17 cells, Interleukin-17A (IL-17) and neutrophilia have been implicated in more severe forms of disease. How Th2-dependent allergic reactions are influenced by Th17 and IL-17- $\gamma \delta$ T cells is poorly understood. In murine models, under some conditions, IL-17 promotes Th2-biased airway inflammatory responses. However, IL-17- $\gamma \delta T$ cells have been implicated in the inhibition and resolution of allergic airway inflammation and hyperresponsiveness (AHR).

Methods: We compared airway responses in Balb/c mice sensitized to OVA with (and without) a Th2-skewing aluminum-based adjuvant and the IL-17 skewing, complete Freund's adjuvant (CFA). AHR was measured invasively by flexiVent, while serum OVA-IgE was quantified by an enzyme immunoassay. Airway inflammatory and cytokine profiles, and cellular sources of IL-17 were assessed from bronchoalveolar lavage and/or lungs. The role of $\gamma \delta T$ cells in these responses was addressed in OVA/CFA sensitized mice using a $\gamma \delta \mathrm{T}$ cell antibody.

Results: Following OVA challenge, all mice exhibited mixed eosinophilic/neutrophilic airway inflammatory profiles and elevated serum OVA-IgE. Whereas OVA/alum sensitized mice had moderate inflammation and AHR, OVA/CFA sensitized mice had significantly greater inflammation but lacked AHR. This correlated with a shift in IL-17 production from CD4 ${ }^{+}$to $\gamma \delta$ T cells. Additionally, OVA/CFA sensitized mice, given a $\gamma \delta$ TCR stimulatory antibody, showed increased frequencies of IL-17- $\gamma \delta T$ cells and diminished airway reactivity and eosinophilia.

Conclusions: Thus, the conditions of antigen sensitization influence the profile of cells that produce IL-17, the balance of which may then modulate the airway inflammatory responses, including AHR. The possibility for IL-17- $\gamma \delta$ T cells to reduce AHR and robust eosinophilic inflammation provides evidence that therapeutic approaches focused on stimulating and increasing airway IL-17- $\gamma \delta$ T cells may be an effective alternative in treating steroid resistant, severe asthma.
\end{abstract}

Keywords: Asthma, Interleukin-17, $ү \delta$ T cell, Adjuvant, Complete Freund's adjuvant

\section{Background}

Asthma is a complex disease characterized by airway inflammation, hyperresponsiveness (AHR) and variable airflow obstruction [1,2] mediated, at least in part, by an aberrant T helper (Th)2 [2-4] and/or Th17 response [5-7]. Th2 cells and the associated cytokines, interleukin (IL)-4, IL-5 and IL-13, are increased in the bronchoalveolar lavage (BAL), sputum and bronchial biopsies of asthmatics and are linked to airway eosinophilia, IgE and reduced lung function $[3,4,8,9]$. Th17 cells and their prime effector

\footnotetext{
* Correspondence: elizabeth.fixman@mcgill.ca

Meakins-Christie Laboratories, McGill University, 3626 St. Urbain Street, Montreal, Quebec H2X 2P2, Canada
}

\section{Biomed Central}

cytokine, IL-17A (hereafter referred to as IL-17), have more recently been implicated in asthma pathogenesis. IL-17 expressing cells are increased in the BAL, sputum, bronchial biopsies and in peripheral blood of asthmatics [5-7] and are correlated with neutrophilic airway inflammation and resistance to corticosteroid treatment in moderate-to-severe asthmatics [10-12]. Although much of the human data is approached from either the Th2 or Th17 perspective, they are unlikely to be mutually exclusive. Asthmatics have been reported to have increases in both Th2- and Th17-related cytokines [13,14] and Cosmi et al. have reported increases in a unique subset of $\mathrm{CD} 4^{+} \mathrm{T}$ cells expressing both IL-4 and IL-17 [15]. Asthmatics can also 
present with a combined eosinophilic/neutrophilic airway inflammatory profile $[16,17]$, which may reflect a mixed immune response.

Eosinophilic airway inflammation, AHR and mucus production are features of asthma that have been successfully modeled in Th2-driven experimental asthma in the mouse $[18,19]$. A widely used method of antigen sensitization involves intraperitoneal (IP) injection(s) of ovalbumin (OVA) adsorbed to an aluminum-based adjuvant (hereafter referred to as alum), a potent inducer of the Th2 response [20]. Comparatively, animal studies of IL-17 show an important role for Th17 cells on airway neutrophilia and steroid resistance [21,22]. Intranasal instillations, as well as epicutaneous routes of OVA sensitization, have been shown to induce a more robust IL-17 response compared to IP injections of OVA/alum $[23,24]$. Furthermore, complete Freund's adjuvant (CFA), a strong inducer of IL-17 typically used in experimental autoimmune encephalomyelitis models, has seen limited use as an IL-17-skewing adjuvant in murine models of allergic asthma [22,25].

The Th2/IL-17 relationship has been assessed in different Th2-driven models of experimental asthma. A growing body of evidence suggests that IL-17, when sourced from Th17 cells, enhances Th2-induced eosinophilic inflammation and AHR $[24,26]$, whereas we and others have shown that IL-17- $\gamma \delta$ T cells negatively regulate these responses [27,28]. We have now compared how two widely used adjuvants, alum and CFA, modulate OVA-induced allergic airways disease. Our primary goals were to induce a mixed Th2/IL-17 inflammatory response and to identify the cellular source(s) of IL-17. Following airway OVA challenge, OVA/alum and OVA/CFA sensitized mice exhibited antigen-induced airway eosinophilia and had similar total $\mathrm{IL}-17^{+}$and Th17 BAL fluid cell numbers. However, the influx of inflammatory cells into the lung, as well as serum OVA-IgE levels, and BAL fluid IL-17- $\gamma \delta \mathrm{T}$ cells were all significantly enhanced in OVA/CFA over OVA/alum sensitized mice following OVA challenge. Nevertheless, AHR was completely absent in these highly inflamed animals, which corresponded to a shift in IL-17 production from $\mathrm{CD}^{+}$to $\gamma \delta \mathrm{T}$ cells. Our secondary goal was to define the role of IL-17- $\gamma \delta$ T cells on AHR and inflammation. In mice treated with a $\gamma \delta$ TCR stimulatory antibody, the frequency of IL-17- $\gamma \delta \mathrm{T}$ cells in OVA/CFA sensitized mice was increased. Consistent with a negative regulatory role for these cells, AHR and eosinophilia were both significantly decreased in these mice. Overall, our data demonstrate that the conditions of initial antigen sensitization direct production of IL-17 from different populations of cells, which in turn, may have the ability to modulate Th2-biased airway inflammatory responses. These data also suggest that specific enhancement of IL-17- $\gamma \delta$ T cells could inhibit allergic airways responses.

\section{Methods}

\section{Animals}

Wild type Balb/c mice originating from Charles River Laboratories (Montreal, QC, Canada) were bred and used at ages 6-10 weeks at the Meakins-Christie Laboratories Animal Facility. Animal studies were approved by the McGill University Animal Care Committee and performed following the Canadian Council on Animal Care guidelines.

\section{Sensitization \& airway challenge}

Mice were sensitized intraperitoneally (IP) with $100 \mu \mathrm{g}$ OVA (Sigma-Aldrich, St. Louis, Missouri, USA) in sterile PBS with either a $10 \%$ solution of Imject Alum (Thermo Scientific, Rockford, Illinois, USA), a 50\% emulsion of Complete Freund's Adjuvant (Sigma-Aldrich) or without adjuvant on days $0 \& 7$. Each OVA group had a respective control group injected without OVA. All mice were lightly anaesthetized with isoflurane and challenged intranasally (IN) with $30 \mu \mathrm{l}$ of PBS containing $50 \mu \mathrm{g}$ of OVA on days $28,29 \& 30$ and sacrificed 24 hours after the last airway challenge.

\section{$\gamma \delta$ TCR antibody treatment}

Balb/c mice were OVA/CFA sensitized and OVA challenged according to the protocol above, with the following exceptions: mice were alternatively challenged on days 42 , $43 \& 44$ and received a total of two $80 \mu \mathrm{g}$ IV injections of the UC7-13D5 $\gamma \delta$ TCR antibody or Armenian hamster isotype control antibody (Biolegend, San Diego, California, US) 2 days and 6 hours before the first airway challenge. Flow cytometry analysis of BAL fluid and lung cells confirmed an increase in the frequency of IL-17- $\gamma \delta$ T cells in mice receiving the $\gamma \delta$ TCR stimulatory antibody.

\section{Analysis of airway hyperresponsiveness \& airway inflammation}

The AHR readouts, resistance and elastance, were taken from mice anaesthetized with a cocktail of xylaxine and sodium pentobarbital, followed by an injection of the paralyzing agent, pancuronium bromide. Measurements were determined using the flexiVent small animal ventilator (SCIREQ, Montreal, Quebec, Canada) by exposing mice to increasing concentrations of aerosolized methacholine. Following assessment of AHR, BAL was performed. Cells, recovered from two- $1 \mathrm{ml}$ PBS lavages of the airways, were pooled and red blood cells lysed before counting total cells. A portion of the cells was centrifuged onto glass slides and stained using Diff-Quick (Fisher Scientific, Ottawa, Ontario, Canada) from which a differential cell count, based on a 300 cell count from five to ten fields, was obtained. BAL fluid from the first lavage was frozen and maintained at $-80^{\circ} \mathrm{C}$ for later cytokine/ chemokine protein analysis. 


\section{Detection of OVA-specific lgE}

Preceding removal of the lungs, the chest cavity was opened and blood collected by cardiac puncture. The blood was left at room temperature for $30 \mathrm{~min}$ to facilitate coagulation before centrifugation and separation of serum for storage at $-80^{\circ} \mathrm{C}$ for future analysis. OVA-specific IgE was quantified using a modified protocol of the ELISA MAX mouse IgE kit (Biolegend, San Diego, California, USA). The kit protocol was followed with the following exceptions: wells used to measure OVA-specific IgE from serum samples were coated with $100 \mu \mathrm{l}$ of a $20 \mu \mathrm{g} / \mathrm{ml}$ OVA solution overnight at $4{ }^{\circ} \mathrm{C}$ in place of the coating antibody. Serum samples were incubated with an equal volume of protein $\mathrm{G}$ sepharose overnight at $4^{\circ} \mathrm{C}$. Following centrifugation, the supernatants were added to wells during the sample incubation step.

\section{Preparation of lung cells}

The right lung was stored in RNAlater (Ambion, Carlsbad, California, USA) at $-20^{\circ} \mathrm{C}$ for analysis by real-time PCR. A single cell suspension of lung cells was obtained from the left lung of each mouse by first mincing the lung and then incubating the tissue in $1 \mathrm{ml}$ of serum-free DMEM (Life Technologies, Carlsbad, California) containing Liberase TM (100 $\mu \mathrm{g} / \mathrm{ml}$; Roche, Indianapolis, Indiana, USA) combined with collagenase XI $(250 \mu \mathrm{g} / \mathrm{ml})$, hyaluronidase 1a $(1 \mathrm{mg} / \mathrm{ml})$ and DNase I (200 $\mu \mathrm{g} / \mathrm{ml}$, Sigma-Aldrich) for $1 \mathrm{~h}$ at $37^{\circ} \mathrm{C}$. The reaction was stopped with a $20 \mathrm{mM}$ final concentration of EDTA [29]. Red blood cells were lysed following enzymatic digestion.

\section{Flow cytometric analysis}

Single cell preparations of BAL and lung cells were incubated for $4 \mathrm{~h}$ in $1 \mathrm{ml}$ of RPMI media containing $1 \%$ penicillin/streptomycin, $10 \%$ heat-inactivated fetal bovine serum (Life Technologies); $0.67 \mu \mathrm{l} / \mathrm{ml}$ GolgiStop from the Cytofix/Cytoperm Fixation/Permeabilization Kit (BD Biosciences, San Diego, California, USA); $50 \mathrm{ng} / \mathrm{ml}$ phorbol 12-myristate 13-acetate (PMA) and $500 \mathrm{ng} / \mathrm{ml}$ ionomycin (Sigma-Aldrich). Surface and intracellular cytokine staining were performed according to the kit protocol. Cells were double or triple stained with a combination of the following antibodies: $\alpha$-CD4-Pacific Blue, $\alpha-\gamma \delta$ TCR-Fluorescein Isothiocyanate (GL3 clone), $\alpha$-IL-17AlexaFluor 647, $\alpha$-CD3-Pacific Blue (BD Biosciences) or $\alpha-V \gamma 4$-Fluorescein Isothiocyanate (UC3-10A6 clone) (Biolegend). Stained cells were processed using an LSRII flow cytometer (BD Biosciences) and analyzed using FlowJo software (Tree Star, Inc., Ashland, Oregon, USA).

\section{RNA purification \& real time PCR analysis}

Lung tissue was homogenized and total RNA isolated following the PureLink RNA Mini Kit (Ambion) protocol. RNA was reverse-transcribed into cDNA using Oligo dT primers and SuperScript II (Life Technologies). Real-time quantitative PCR amplification was performed with Power SYBR Green (Applied Biosystems, Warrington, UK) using the Applied Biosystems PCR system. Cycle threshold values were first normalized to Gapdh gene expression before quantification by the comparative threshold cycle method to obtain the gene expression levels from lungs of OVA sensitized and challenged mouse groups, relative to the saline control group [30].

\section{Quantitative analysis of BAL fluid mediators}

BAL fluid cytokine and chemokine levels were quantified with the Q-View Imager using the 16-plex mouse cytokine screen (Quansys Biosciences, Logan, Utah, USA). IL-13 levels in the BAL fluid were quantified using the ELISA Ready-SET-Go kit (ebioscience, San Diego, California, USA).

\section{Statistical analysis}

Data are expressed as the mean +SEM. Multiple comparisons (i.e. antigen- and adjuvant-dependent effects) were analyzed by two-way ANOVA, followed by the Holm-Sidak post hoc test. Single comparisons (between the 3 OVAsensitized groups) were analyzed by one-way ANOVA, followed by the Holm-Sidak post hoc test. Single comparisons (between the 2 antibody treated groups) were analyzed by an unpaired, two-tailed $\mathrm{t}$-test. $\mathrm{p}$-values less than 0.05 were considered statistically significant. Figures and statistics were analyzed using GraphPad Prism 6 (La Jolla, California, USA).

\section{Results}

Enhanced airway inflammation, but lack of AHR, in mice sensitized to OVA in the presence of CFA

In order to establish a mixed model of allergic asthma in which the IL-17 response could be assessed within an in vivo Th2 environment, we intraperitoneally (IP) sensitized mice with OVA in the absence (OVA/sal group) or presence of the adjuvants, alum (OVA/alum group) or CFA (OVA/CFA group). We confirmed induction of several classic features associated with allergic airways disease and differentiated OVA-specific (\$) from adjuvantspecific (*) effects (Figure 1). OVA-IgE was selectively detected in all OVA sensitized and challenged mice and was present at significantly higher levels in OVA/CFA mice (Figure 1A). Total cells, eosinophils, neutrophils and lymphocytes were significantly increased in the BAL fluid of OVA/CFA sensitized mice (solid bar) compared to the CFA control (striped bar). In contrast, inflammation was not significantly changed in OVA/sal mice and only eosinophils were significantly increased in OVA/alum sensitized mice (Figure 1B). Moreover, following OVA challenge, OVA/CFA mice had significantly more macrophages, eosinophils, neutrophils and lymphocytes, resulting in 3 


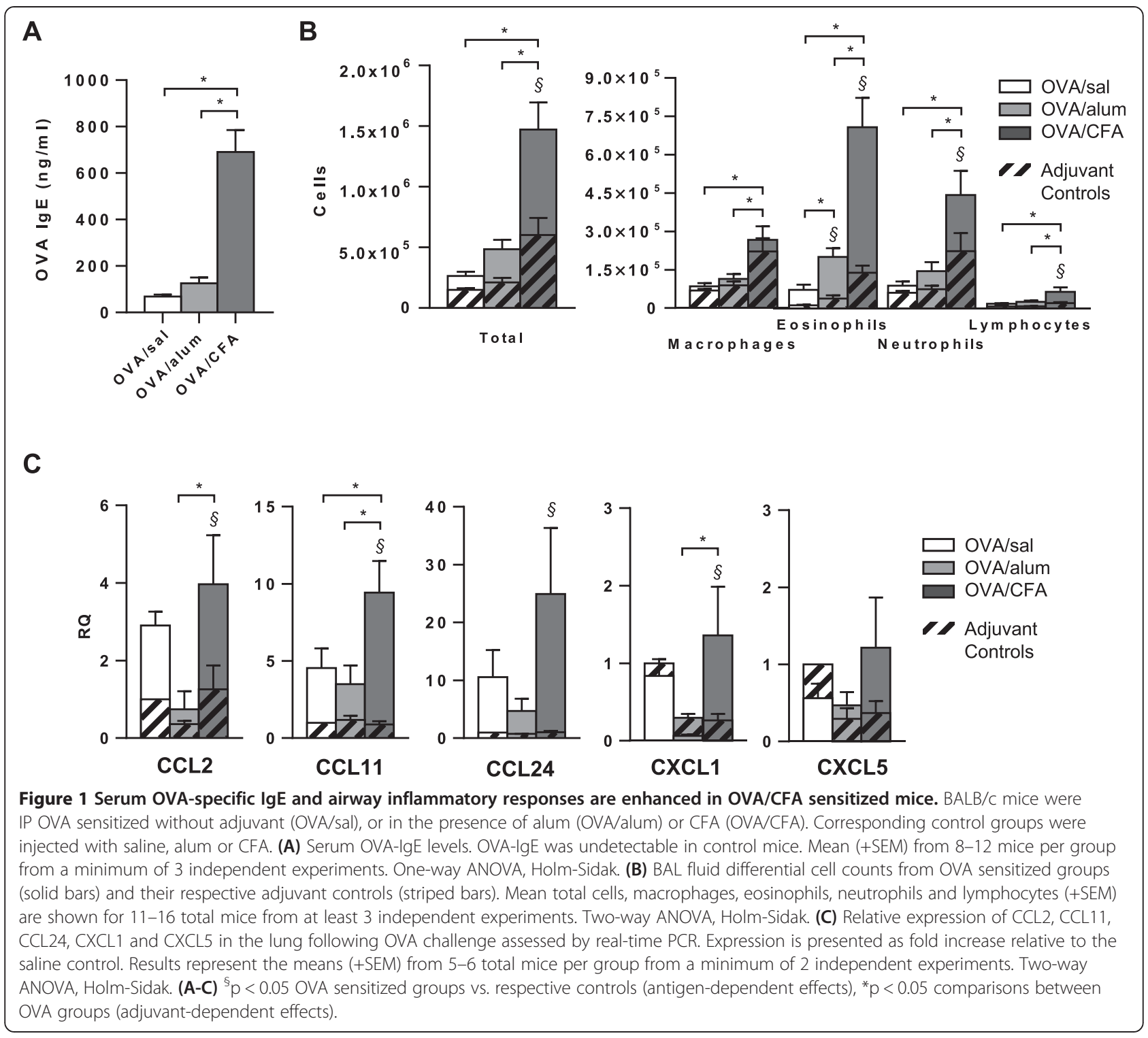

and 5.5 fold more total cells recovered compared to OVA/ alum and OVA/sal mice, respectively. With regard to BAL fluid cell frequencies, eosinophils were increased in all OVA-sensitized mice compared to their respective controls, primarily at the expense of macrophages (Additional file 1: Figure S1). OVA/alum sensitized and challenged mice had greater frequencies of BAL fluid eosinophils than OVA/sal mice, while OVA/CFA mice had greater frequencies of eosinophils, as well as lower frequencies of both macrophages and lymphocytes compared to OVA/sal. Regardless of adjuvant, a mixed eosinophilic/ neutrophilic inflammatory profile was observed in all OVA sensitized groups following OVA challenge.

To assess possible mechanisms by which inflammatory cell recruitment differed, differences in lung chemokine expression were assessed following OVA challenge. Levels of mRNA encoding the macrophage chemoattractant, CCL2 (MCP-1), the eosinophil chemoattractants CCL11 (eotaxin-1) and CCL24 (eotaxin-2), and the neutrophil chemoattractant, CXCL1, were increased in OVA/CFA sensitized mice compared to OVA/sal and/or OVA/alum sensitized mice with these differences reaching statistical significance for CCL2, CCL11, and CXCL1 (Figure 1C). Consistent with the overall increase in BAL fluid inflammatory cell influx, mRNA levels for several chemokines were greater in OVA/CFA mice compared to OVA/sal and/or OVA/alum mice. Moreover, OVA/CFA mice were also the only group to show any significant OVA-specific increases in chemokine expression, with the exception of the neutrophil chemoattractant, CXCL5.

Following OVA challenge, airway resistance (Figure 2A) and elastance (Figure 2B) were significantly increased in 


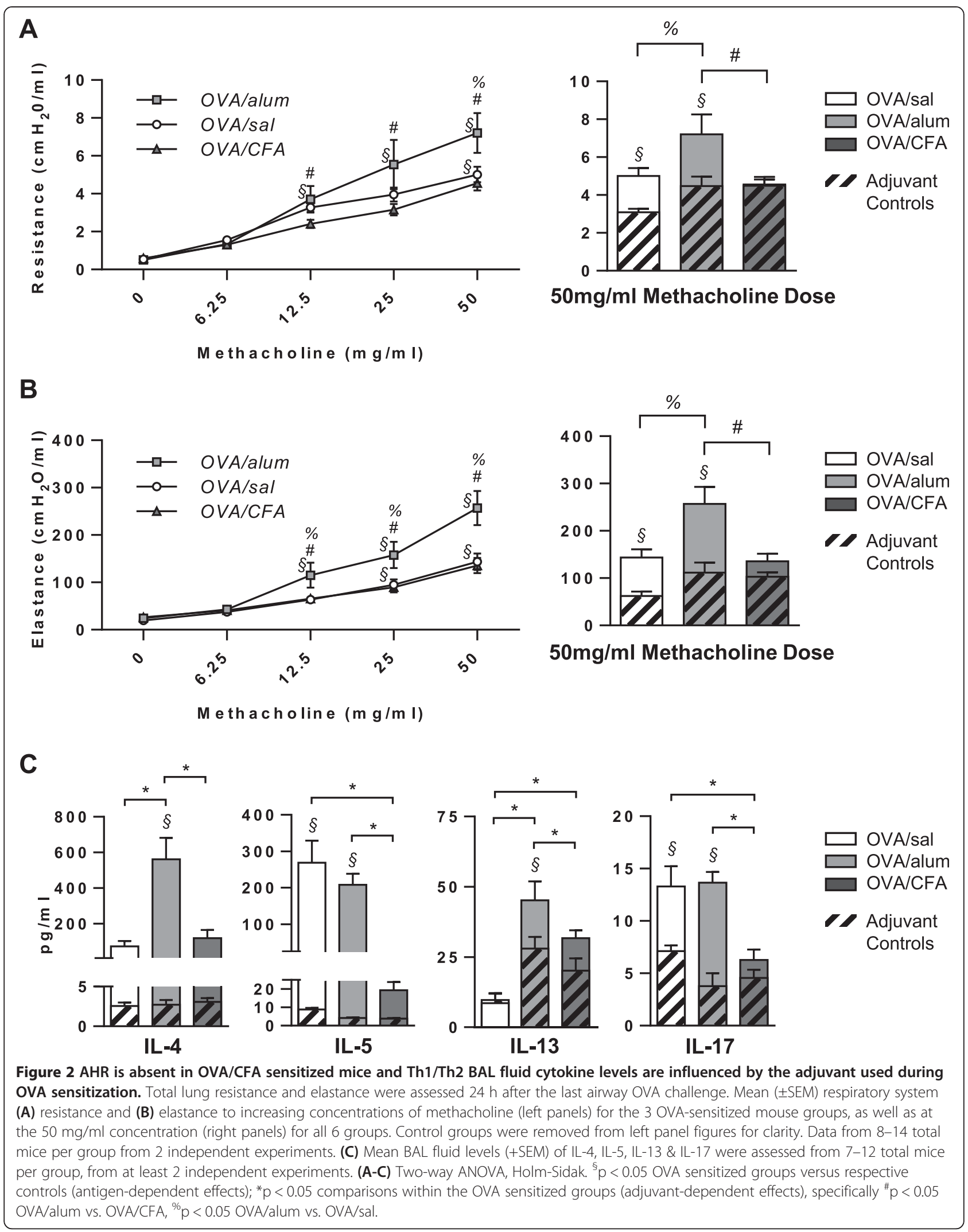


OVA/alum sensitized mice compared to OVA/CFA mice, across multiple concentrations of methacholine (left panels), and to OVA/sal mice at the highest dose (right panels). Moreover, the OVA-dependent increases $(\mathbb{S})$ in airway resistance and elastance that were observed in OVA/alum (and OVA/sal) sensitized mice were completely absent in OVA/CFA sensitized mice. Thus, although OVA-IgE and airway inflammation were significantly enhanced in OVA/ CFA sensitized mice (Figure 1A, B), AHR was absent. Although adjuvant-only controls showed subtle differences in respiratory resistance and elastance at the $50 \mathrm{mg} / \mathrm{ml}$ methacholine dose (Figure 2A and B, right panels), these differences were not statistically different. BAL fluid was analyzed for Th1, Th2 and Th17 related cytokines. Levels of IFN- $\gamma$ were generally low in all groups (data not shown). In OVA/sal sensitized mice, OVA challenge increased levels of IL-5 and IL-17 (Figure 2C). OVA/alum sensitized mice had increased IL-4, IL-5, IL-13 and IL-17 levels compared to alum-sensitized mice, post airway challenge. OVA/alum mice also had significantly greater levels of these cytokines compared OVA/sal and/or OVA/CFA mice. Interestingly, OVA/CFA sensitized mice showed no differences in cytokine levels compared to CFA-sensitized mice.

\section{When emulsified with OVA at sensitization, CFA increases IL-17- $\gamma \delta$ T cell numbers in the BAL fluid}

Following OVA challenge, IL-17 expressing cells were present in the BAL fluid of all mice, regardless of the conditions of OVA sensitization (Figure 3A). Although there was a trend toward a reduced frequency of $\mathrm{IL}-17^{+}$ cells in mice sensitized with OVA/CFA, this difference did not reach statistical significance (Figure 3B). Nevertheless, when taking into account the overall inflammatory cell influx into the BAL fluid, OVA/CFA sensitized mice had larger numbers of IL- $17^{+}$cells compared to the other OVA sensitized groups, though this difference was only significant when compared to the OVA/sal group (Figure 3C). No antigen-dependent differences were observed in the OVA sensitized mouse groups compared to their respective controls.

Several cell types, including Th17 cells [24,31], $\gamma \delta \mathrm{T}$ cells $[27,28]$ and alveolar macrophages [32] have been identified as sources of IL-17 in murine models of allergic airways disease. Following OVA challenge, we identified the major IL-17 producing cell(s) in both the BAL and lungs of OVA/sal, OVA/alum and OVA/CFA sensitized mice. After gating on $\mathrm{IL}-17^{+}$cells, the major sources of IL-17 were identified as $\mathrm{CD}^{+}{ }^{+}$(Th17) and $\gamma \delta(\mathrm{IL}-17-\gamma \delta) \mathrm{T}$ cells, though the ratio differed depending on the conditions of OVA sensitization (Figure 4A). The ratio of the frequency of IL-17- $\gamma \delta$ to Th17 cells in the BAL fluid established that Th17 cells were the major source of IL-17 in OVA/sal sensitized mice; that Th17 and IL-17- $\gamma \delta \mathrm{T}$ cells contributed almost equally to IL-17 production in OVA/alum sensitized mice; and that IL-17- $\gamma \delta$ T cells were the main producers of IL-17 in OVA/CFA sensitized mice (Figure 4B). Similar total numbers of Th17 cells were present in the BAL fluid of all OVA sensitized and challenged mice (Figure 4C), but greater numbers of total IL-17- $\gamma \delta \mathrm{T}$ cells were recovered from OVA/CFA sensitized mice compared to OVA/alum and OVA/sal mice. Only the OVA/alum group had significantly greater numbers of Th17 cells compared to its respective control (Figure 4C, left panel), whereas antigen-dependent differences were absent for total IL-17- $\gamma \delta$ T cells (Figure 4C, right panel). The ratios of total IL- $17-\gamma \delta$ to Th17 cells for all OVA sensitized mouse groups were similar to the ratios of the frequencies of the same cells (Figure 4D), with OVA/CFA sensitized mice having a significantly larger ratio to both OVA/sal and OVA/alum mice. The median fluorescence intensity (MFI) of IL-17 was greater in IL-17$\gamma \delta \mathrm{T}$ cells compared to Th17 cells from the BAL fluid (Additional file 1: Figure S2A, B) for all OVA sensitized groups, indicating that, while the frequencies of cell types expressing IL-17 were modified by the type of adjuvant present at sensitization, the amount of IL-17 expressed by these individual cells was not affected.

\section{Activating IL-17- $\gamma \delta$ T cells leads to inhibition of airway eosinophilia and AHR}

To examine the impact of elevated numbers of IL- $-17-\gamma \delta$ $\mathrm{T}$ cells present in mice sensitized with OVA/CFA, these mice were treated with a $\gamma \delta$ TCR antibody, UC7-13D5. Consistent with a study demonstrating that this antibody activates $\gamma \delta \mathrm{T}$ cells in vitro and in vivo [33], UC7-13D5 treated OVA/CFA sensitized mice exhibited increased frequencies of BAL fluid IL-17- $\gamma \delta \mathrm{T}$ cells (Figure 5A, B left panel) and, interestingly, $\mathrm{IL}^{-17^{+}}$cells (Figure 5A, C left panel), post airway challenge. There was also a positive trend for the number of IL-17- $\gamma \delta$ T cells and IL- $17^{+}$ $\mathrm{T}$ cells to be increased in UC7-13D5-treated mice (right panels of Figure 5B and C). The majority of the IL$17-\gamma \delta \mathrm{T}$ cells in the UC7-13D5-treated mice were of the Vy4 subset (Additional file 1: Figure S3A, B), which has previously been shown to inhibit AHR and airway inflammation in murine models of asthma [28]. In agreement, BAL fluid eosinophils (Figure 6A, B) were significantly decreased in antibody treated mice compared to recipients of isotype control antibodies. Moreover, the frequency of BAL fluid neutrophils was also increased (Figure 6B), which may reflect the increase in total IL-17 expressing cells in mice treated with the UC7-13D5 antibody. Finally, both respiratory resistance and elastance were diminished in OVA/CFA mice treated with the UC7-13D5 antibody, again consistent with a negative regulatory role for $\mathrm{IL}-17-\gamma \delta \mathrm{T}$ cells (Figure 6C). 


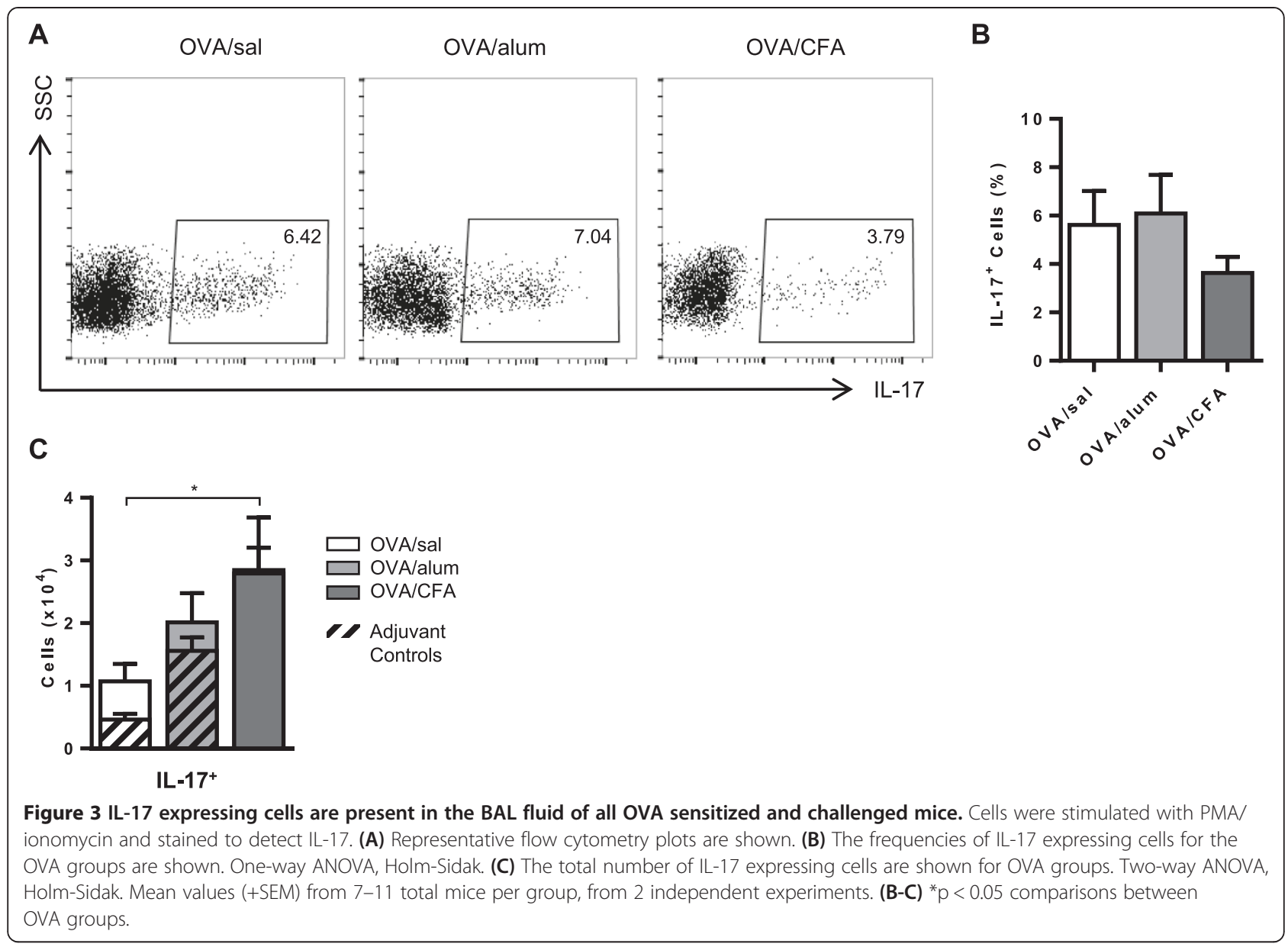

\section{Discussion}

In rodent models of allergic airways disease, the types of antigen and adjuvant, as well as their concentration, route and timing of delivery can impact the nature of the ensuing immune response. Historically, the most widely used murine models of allergic asthma and rhinitis have relied upon IP injections of OVA adsorbed to an aluminum-based adjuvant [34,35]. This class of adjuvant has been used extensively in animal models of allergic airways disease for its ability to induce a Th2-biased immune response [20,36]. In contrast, CFA has been recognized as a Th17-promoting adjuvant and is comprised of a light mineral oil, a surfactant agent, and heat-killed Mycobacterium tuberculosis (Mtb) that creates an emulsion when mixed with an aqueous solution [37]. A great deal of our understanding of the IL-17/CFA relationship has come from experimental autoimmune encephalomyelitis models of multiple sclerosis [38]. Nevertheless, antigen sensitization with CFA has rarely been used in models of allergic airways disease. Our goal was to assess how the choice of adjuvant-alum or CFA—affected Th2 and Th17 type inflammatory responses in the airways post antigen challenge.
CFA has been widely used in experimental studies for its unsurpassed ability to enhance antibody production against a number of different antigens [37]. This was confirmed in our analysis as OVA/CFA sensitized mice, post airway challenge, had significantly greater levels of serum OVA IgE compared to both OVA/sal and OVA/ alum sensitized mice. Abundant data demonstrate that, independent of the mouse strain, mice IP sensitized with OVA/alum have robust airway eosinophilia post challenge $[34,35]$. Nevertheless, the airways of $\mathrm{C} 57 \mathrm{Bl} / 6$ mice sensitized IP with OVA/alum or OVA/CFA can also exhibit a mixed eosinophilic/neutrophilic inflammatory profile of similar magnitude following acute antigen challenge [22]. Our data indicate that Balb/c mice IP sensitized to OVA with alum or CFA yield mixed eosinophilic/ neutrophilic inflammatory profiles where equal ratios of both cell types were recovered in the BAL fluid. These data suggest that both Th2 and IL-17 responses, which are associated with airway eosinophilia [39] and neutrophilia [21], respectively, may be induced with either adjuvant. Although AHR is often correlated with airway inflammation, there is evidence from humans $[40,41]$, as well as murine models [42,43], that AHR can occur 


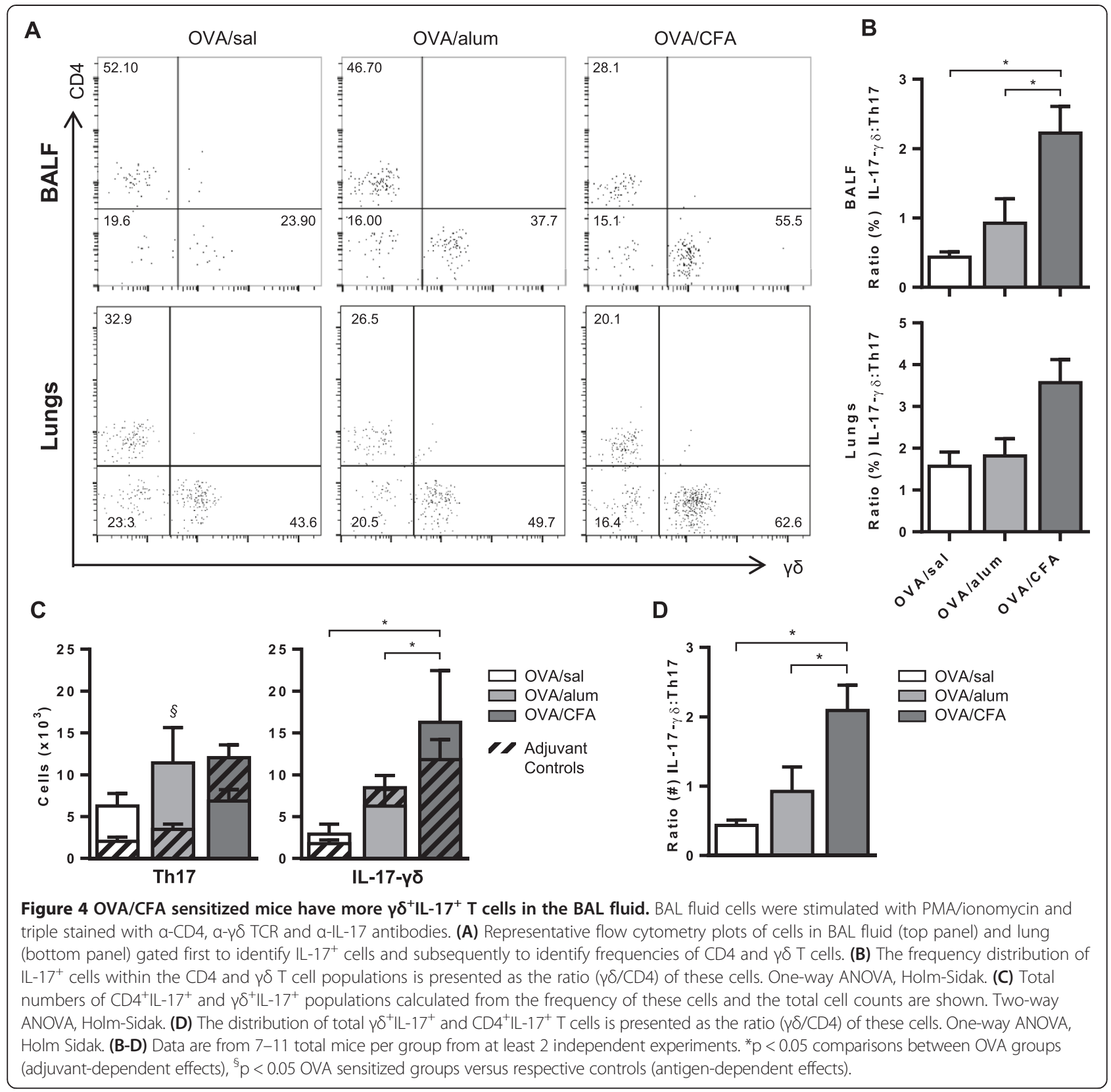

independently of inflammation. Our data indicate that mice sensitized with OVA/CFA had significantly more inflammation following OVA challenge, as assessed from the BAL fluid. Nevertheless, both antigen- and adjuvantspecific increases in airways resistance and elastance were completely absent in these mice. Comparatively, OVA/ alum sensitized mice exhibiting moderate inflammation, had both antigen- and adjuvant-dependent increases in AHR. These differences in airways resistance and elastance may be related to BAL fluid levels of IL- 4 and IL-13, which were elevated in only the OVA/alum sensitized mice. Intratracheal instillations of IL-13 to naïve mice [44] or IL-4 to IL-13 deficient mice can induce AHR [21]. Interestingly, the same studies showed IL-4 and IL-13 to be potent inducers of airway eosinophilia, whereas in our study, airway hyporesponsive, highly eosinophilic OVA/ CFA sensitized mice had comparatively lower BAL fluid levels of both cytokines. We therefore considered other mediators to provide a possible explanation for the disconnect between AHR and inflammation observed in OVA/CFA mice. The ability of IL-17 to act as both a positive and negative regulator of asthma [27], as well as the ability of CFA to induce IL-17 in models of experimental autoimmune encephalomyelitis [45] made this particular 
A

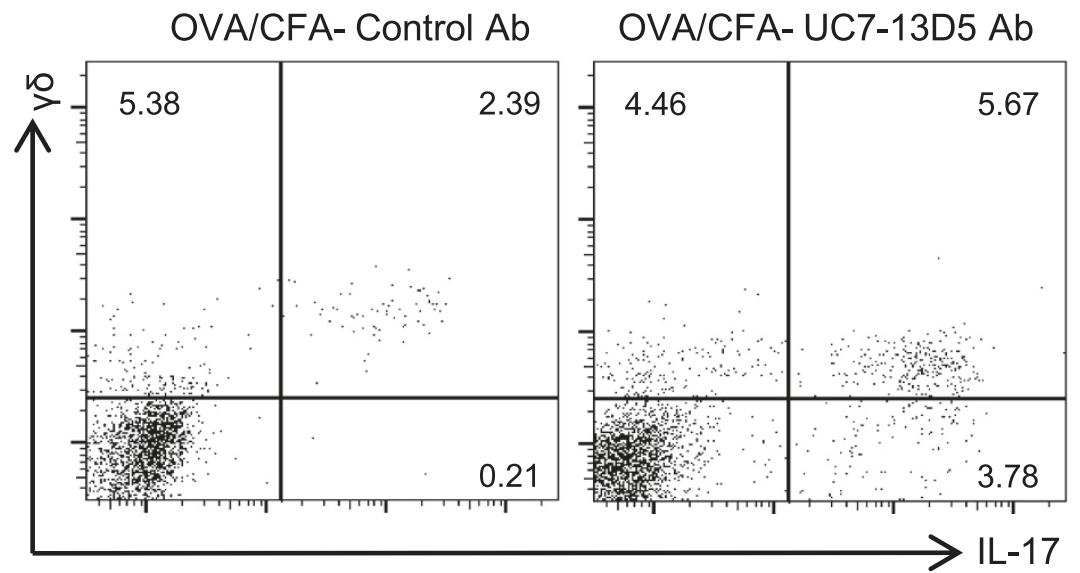

B

$\square$ OVA/CFA- Control Ab

$\square$ OVA/CFA- UC7-13D5 Ab
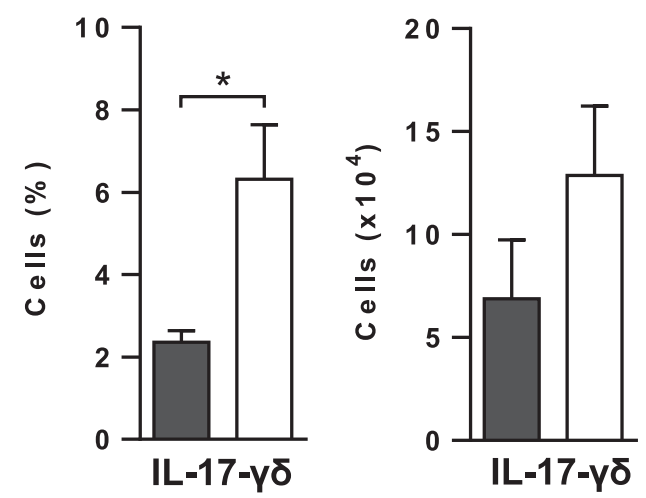

C

$\square$ OVA/CFA- Control Ab

$\square$ OVA/CFA- UC7-13D5 Ab
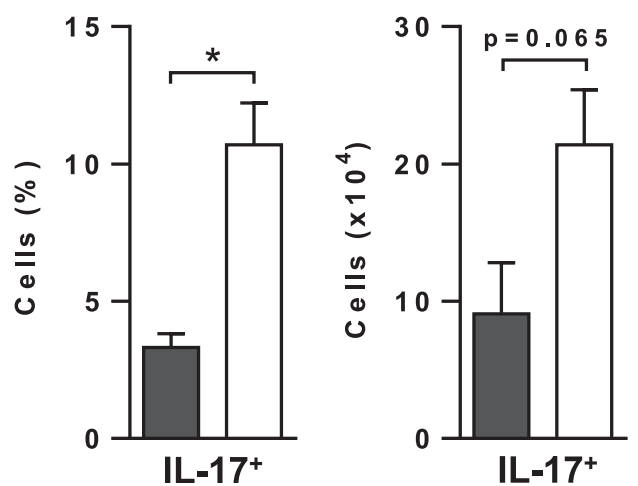

Figure $\mathbf{5}$ (See legend on next page.) 
(See figure on previous page.)

Figure 5 Frequencies of total IL-17 expressing cells and of IL-17- $\gamma \delta$ cells are increased in OVA/CFA sensitized mice treated with a $\gamma \delta$ TCR stimulatory antibody. OVA/CFA sensitized mice were IV injected with a $\gamma \delta$ TCR stimulatory antibody (UC7-13D5) or isotype control before airway challenge. BAL fluid cells were stimulated with PMA/ionomycin and stained with $a-\gamma \delta$ TCR and $a-I L-17$ antibodies. (A) Representative flow cytometry plots of BAL fluid cells. The mean frequencies (left panels) and numbers (right panels) of (B) IL-17- $\gamma \delta$ and (C) IL-17 ${ }^{+}$BAL fluid cells are presented for 5 total mice per group from 2 independent experiments. (B-C) Unpaired, two-tailed t-test. ${ }^{*} p<0.05$.

cytokine a strong candidate. While IL-17 alone may not induce AHR in mice, under some circumstances it can promote Th2-dependent AHR and inflammation [26].

We identified the cellular source(s) of IL-17 in mice sensitized under different adjuvant conditions. Following OVA challenge, IL-17 was expressed predominantly by a combination of $\mathrm{CD}^{+}$and $\gamma \delta \mathrm{T}$ cells in the BAL fluid and lungs (Figure 4A) of all OVA-sensitized and challenged mice. However, in OVA/sal sensitized mice, IL-17 was produced primarily by $\mathrm{CD}^{+} \mathrm{T}$ cells. Alum or CFA, given at the time of sensitization, affected this distribution by skewing IL-17 expression toward $\gamma \delta$ T cells. $M t b$, an essential component of CFA, preferentially induces IL-17 expression from $\gamma \delta$ T cells rather than CD4 ${ }^{+} \mathrm{T}$ cells through activation of the Nalp3 inflammasome $[45,46]$. Moderate skewing of IL-17 production toward $\gamma \delta$ T cells also occurred in mice sensitized with OVA/alum. This may reflect the ability of alum to activate the Nalp3 inflammasome $[35,47]$, albeit less potently than CFA, or depend on the quantity of alum used at sensitization.

Our data demonstrating that IL-17- $\gamma \delta \mathrm{T}$ cells, Th17 cells (Figure 4C) and total IL-17 ${ }^{+}$cells (Figure $3 \mathrm{C}$ ) recovered in the BAL fluid did not necessarily coincide with BAL fluid levels of IL-17 (Figure 2C), are consistent with data from other groups [24,28]. For example, IL-17 levels in the BAL fluid of both airway and IP sensitized mice were undetectable at a time point when total Th17 cells, assessed by flow cytometry, were significantly higher in airway sensitized mice [24]. Thus, apparent differences in IL-17 cytokine levels relative to IL-17 expressing cells may simply reflect the timing of assessment, as the ability to detect IL-17 in the BAL fluid may be quite transient $[24,28]$, whereas detection of cells with the potential to produce IL-17 may be more stable/longlasting.

In murine models of allergic asthma, IL-17 expression is most often associated with $\mathrm{CD} 4^{+} \mathrm{T}$ cells, although $\gamma \delta \mathrm{T}$ cells and macrophages can also express IL-17 [24,28,32]. Several factors, including the quantity of cytokine produced, as well as the timing and location and cell source, likely impact the outcome of IL-17 production. For example, while Th17 cells appear to promote Th2 responses, such as eosinophil recruitment to the airways, we and others have shown that IL-17- $\gamma \delta \mathrm{T}$ cells actually inhibit Th2-associated AHR and/or inflammation [27]. Murdoch et al. specifically showed that $64 \%$ of IL-17- $\gamma \delta$ T cells were of the ${\mathrm{V} \gamma 4^{+}}^{+}$subset [28]. This specific subset of $\gamma \delta$ T cells actively suppresses AHR [48] and may accomplish this without affecting inflammation [49]. We similarly showed a population of $\mathrm{IL}-17^{+} \mathrm{V} \gamma 4^{+}$cells constituting a large majority of the IL-17- $\gamma \delta \mathrm{T}$ cells in the BAL fluid of OVA/ CFA sensitized mice (Additional file 1: Figure S3). Thus, the prominent IL-17- $\gamma \delta \mathrm{T}$ cell population recovered in OVA/CFA sensitized mice may explain, at least in part, the absence of AHR, despite the robust inflammatory response. For these same reasons, regulatory $\mathrm{T}$ cells are not likely to be involved in the suppression of AHR, due to their well-established role in suppressing inflammation [50].

In order to better understand how IL-17- $\gamma \delta \mathrm{T}$ cells regulated airway inflammatory responses in OVA/CFA sensitized mice, we treated these mice with a $\gamma \delta$ TCR stimulatory antibody (UC7-13D5), the outcome of which was a substantial increase in the frequency of IL-17- $\gamma \delta$ $\mathrm{T}$ cells accompanied by reductions in both AHR and eosinophil influx. We were not surprised to find that the increase in IL-17- $\gamma \delta$ T cells corresponded to a decrease in AHR, in particular since the majority of the IL-17- $\gamma \delta$ $\mathrm{T}$ cells induced in OVA/CFA sensitized mice appeared to be the $V \gamma$, inhibitory subset. Unlike the inhibition of AHR, the reduced number of airway eosinophils in UC7-13D5 treated mice was unexpected as OVA/CFA sensitized mice that followed the 4 week sensitization and challenge protocol had increased IL-17- $\gamma \delta$ T cells in the BAL fluid (Figure 4C) and suppressed AHR (Figure 2A, B), but had highly inflamed airways, including abundant eosinophils (Figure $1 \mathrm{~B}$ ). $\gamma \delta \mathrm{T}$ cells (IL-17 ${ }^{+}$ and $\mathrm{V} \gamma^{+}{ }^{+}$) are described as having either an inhibitory or no effect on airway eosinophilia, based on different OVA models of allergic airways disease [28,48,49]. Careful examination of the literature indicates that this may be a temporal issue. In these OVA models, $\gamma \delta$ T cells are consistently elevated in numbers at the peak of eosinophil recruitment (24-48 hours after the last airway challenge), suggesting that IL-17- $\gamma \delta$ T cells do not have an immediate inhibitory effect on the influx of eosinophils. However, in the days following antigen challenge, (i.e. recovery phase), IL-17- $\gamma \delta$ T cells have specifically been shown to decrease airway eosinophil numbers and further attenuate AHR [28]. Where $\gamma \delta$ T cells are reported as having no effect on eosinophil recruitment, measurements were taken at the peak of inflammation and compared to mice that received a $V \gamma 4$ neutralizing antibody [49], which would neutralize a population of cells that has yet to influence airway eosinophil numbers. In contrast, in our studies, the UC7-13D5 

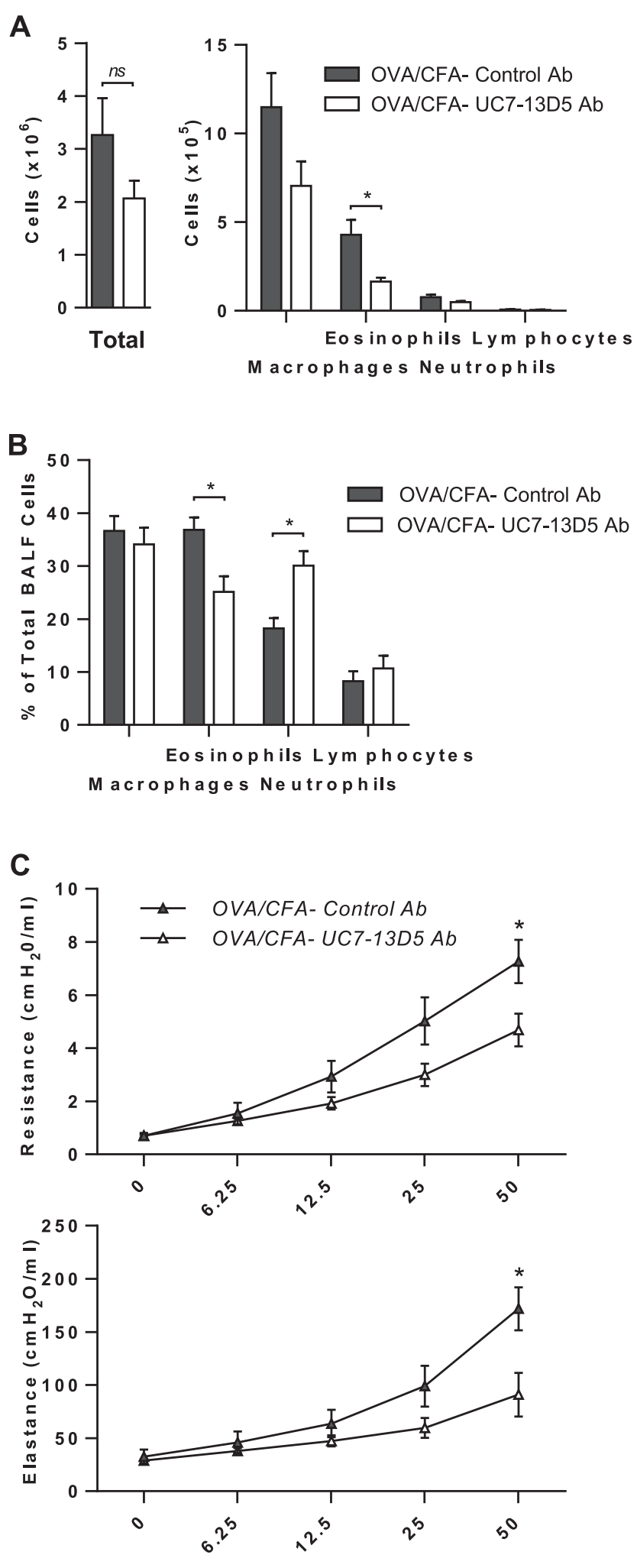

Figure 6 (See legend on next page.) 

cell counts and (B) frequencies of macrophages, eosinophils, neutrophils and lymphocytes (+SEM) are shown for 5 total mice per group from 2 independent experiments. (C) Total lung resistance and elastance were assessed $24 \mathrm{~h}$ after the last airway OVA challenge. Mean ( \pm SEM) respiratory system resistance and elastance to increasing concentrations of methacholine are shown. (A-C) Unpaired, two-tailed t-test. ${ }^{*} p<0.05$, ns $=$ not significant.

antibody, that was given pre-challenge to OVA/CFA sensitized mice, stimulated and thus activated the $\gamma \delta \mathrm{T}$ cells, which may have allowed them to reduce airway eosinophil numbers even at 24 hours after the last airway challenge. Further studies are required to confirm these findings. IL-17- $\gamma \delta$ T cells have been reported to increase IL-17 production from Th17 and other cell types [38,51,52]. This may explain the increase in total $\mathrm{IL}-17^{+}$cells recovered in the BAL fluid of mice treated with the UC7-13D5 antibody. Consistent with the literature, the frequencies of neutrophils in UC7-13D5 treated mice (Figure 6B) reflected the increase in $\mathrm{IL}-17^{+}$cells (Figure $5 \mathrm{C}$ ) [24,53]. However, the overall neutrophil cell count remained low and did not differ between UC7-13D5 and isotype control antibody treated OVA/CFA sensitized mice (Figure 6A).

The UC7-13D5 $\gamma \delta$ TCR antibody has previously been used to functionally deplete $\gamma \delta$ T cells in vivo [54]. Though we used comparable concentrations of this antibody, as discussed above, our data indicate that the target cells were neither neutralized, nor functionally depleted. In fact, our data are consistent with data provided by Koenecke, et al. demonstrating that $\gamma \delta \mathrm{T}$ cells are activated by UC7-13D5 [33]. To study $\gamma \delta$ T cells in OVA/CFA sensitized mice, two different antibodies were used: mice were injected with the UC7-13D5 $\gamma \delta$ TCR antibody, followed by $\gamma \delta \mathrm{T}$ cell detection by flow cytometry using the GL3 $\gamma \delta$ TCR antibody. While the treatment and staining antibodies differ, our data and others [33] suggest that the GL3 and UC7-13D5 antibodies compete for the same $\gamma \delta$ TCR epitope, as the $\gamma \delta$ MFI was lower, but not to the extent of depletion, in BAL fluid cells recovered from UC7-13D5 antibody compared to control antibody treated mice (Figure 5). This was also the case for the Vy4 staining antibody (UC3-10A6 clone), but appeared to compete to a lesser degree with the UC7-13D5 antibody (Additional file 1: Figure S3). In either case, it is clear that the $\gamma \delta$ T cells were not depleted. Furthermore, as discussed above, there was a significant increase in the expression of IL-17 within the $\gamma \delta$ T cells from UC7-13D5 treated mice, while the frequency of total $\gamma \delta \mathrm{T}$ cells was unchanged compared to that in mice treated with the isotype control (data not shown).

Although the adjuvants, alum and CFA, significantly impacted the distribution of IL-17 expression between the $\mathrm{CD} 4^{+}$and $\gamma \delta \mathrm{T}$ cell populations, the median fluorescence intensity (MFI) of IL-17 within each cell type was unaffected. In fact, the MFI of IL-17 in BAL fluid $\gamma \delta \mathrm{T}$ cells was significantly greater than in $\mathrm{CD} 4^{+} \mathrm{T}$ cells for all three OVA sensitized groups. Lockhart et al. discussed the frequency of IL-17 expression within the same cell populations in a murine model of $M t b$ infection [46]. Although they did not directly address the MFI of IL-17, it too appeared to be higher in $\gamma \delta \mathrm{T}$ cells than in $\mathrm{CD} 4^{+} \mathrm{T}$ cells. Therefore, the level of expression of IL-17 in this model, as well as in our model of allergic airways disease, may be applicable to other physiological or pathological lung conditions. We previously demonstrated that a low dose of IL-17 augments IL-13-induced airway inflammatory responses, while a higher dose of IL-17 attenuates these responses [27]. In parallel, the "low dose" of IL-17 produced by $\mathrm{CD} 4^{+} \mathrm{T}$ cells in the current study may have augmented disease while our data suggest that the "high dose" of IL-17 produced by $\gamma \delta \mathrm{T}$ cells attenuated disease.

\section{Conclusions}

Altogether, our data demonstrate that intraperitoneal OVA sensitization with and without the adjuvants, alum and CFA, regulated the profile of IL-17 producing cells localized to the lung post OVA challenge, providing insight into potential mechanisms by which IL-17 may negatively regulate allergic airways disease. Notwithstanding the large influx of inflammatory cells to the airways, AHR was completely absent in OVA/CFA sensitized mice post OVA challenge. This lack of AHR coincided with an increase in IL-17- $\gamma \delta$ T cells in the BAL fluid, in line with previous data demonstrating that these cells are potent inhibitors of airway inflammatory responses [27,28]. While the dual role of IL-17 makes it a complex target for drug development, our data suggest that treatments specifically focused on enhancing the IL-17- $\gamma \delta \mathrm{T}$ cell population may be beneficial for asthmatics.

\section{Additional file}

Additional file 1: Figure S1. Frequencies of macrophages, eosinophils, neutrophils and lymphocytes in the BAL fluid of OVA sensitized mice and their respective controls. 11-16 mice from at least 3 independent experiments. Two-way ANOVA, Holm-Sidak. ${ }^{\S} \mathrm{p}<0.05$ OVA groups vs. their respective controls; ${ }^{*} p<0.05$ versus OVA/sal, $\wedge p<0.05$ versus CFA. Additional relevant comparisons were not significantly different. Figure S2. Frequencies of $\mathrm{IL}-17^{+}$cells within the $\gamma \delta$ T cell population and 
the MFI of IL-17 are greater than those of $\mathrm{CD}^{+} \mathrm{T}$ cells from the BAL fluid. Cells were triple stained with $a-C D 4, a-\gamma \delta$ TCR and $a-I L-17$ antibodies. (A) Representative flow cytometry plots of BAL fluid cells from OVA sensitized groups. $(\triangle)$ indicates the MFI of IL-17 within the IL-17-expressing $\mathrm{CD}^{+}$and $\gamma \delta \mathrm{TCR}^{+}$cell populations on a log scale. (B) The MFI of IL-17 expression within the IL-17 expressing CD4 ${ }^{+}$and $\gamma \delta \mathrm{T}$ cell populations are shown. Flow cytometry plots and mean values (+SEM) are from 7-9 mice per group from at least 2 independent experiments. Two-way ANOVA, Holm-Sidak. ${ }^{*} p<0.05$. Figure S3. The majority of IL-17- $\gamma \delta$ T cells in the BAL fluid of OVA/CFA sensitized mice are of the $V_{\gamma} 4$ subset and increase in frequency with activation by the $\gamma \delta$ TCR antibody. OVA/CFA sensitized mice were IV injected with a $\gamma \delta$ TCR (UC7-13D5) stimulatory antibody or isotype control before airway OVA challenge. BAL fluid cells were double stained with $a-I L-17$ and either the $a-\gamma \delta$ TCR or $a-V \gamma 4$ antibodies. Representative flow cytometry plots of the frequencies of $\gamma \delta^{+} \mid \mathrm{L}-17^{+}$and $\mathrm{V} \gamma 4^{+} \mathrm{IL}-17^{+}$cells from recipients of (A) control or (B) UC7-13D5 antibody are shown within the total live BAL fluid cell population and are representative of 2-3 mice per group.

\section{Abbreviations}

AHR: Airway hyperresponsiveness; BAL: Bronchoalveolar lavage; IP: Intraperitoneal; IN: Intranasal; IV: Intravenous; MFI: Median fluorescence intensity; Mtb: Mycobacterium tuberculosis.

\section{Competing interests}

The authors declare that they have no competing interests.

\section{Authors' contributions}

EMN assisted in the design of the study, drafted the manuscript and carried out all experiments, assays, acquisitions and analysis, except where other authors are specifically credited. JS carried out airway hyperresponsiveness measurements and analysis, and the IL-13 immunoassay. MWK carried out some real time PCR and assisted in flow cytometry and statistical analysis. EDF conceived of and designed the study, coordinated and helped draft the manuscript. All authors read and approved the final manuscript.

\section{Acknowledgements}

The authors are indebted to Dr. Karim Shalaby for helpful comments on the manuscript and to Dr. Karen Yam, Ms. Katie Young and Ms. Angela Brewer for help with the Quansys protein analysis. This work was supported by operating grants to EDF from the McGill University Health Centre Research Institute and the Canadian Institutes of Health Research (MOP 106487). The Meakins-Christie Laboratories-MUHC-RI, are supported in part by a Centre grant from Les Fonds de la Recherche en Santé du Québec (FRSQ).

Received: 2 April 2014 Accepted: 28 July 2014

Published: 14 August 2014

\section{References}

1. Chung KF, Wenzel SE, Brozek JL, Bush A, Castro M, Sterk PJ, Adcock IM, Bateman ED, Bel EH, Bleecker ER, Boulet LP, Brightling C, Chanez P, Dahlen SE, Djukanovic R, Frey U, Gaga M, Gibson P, Hamid Q, Jajour NN, Mauad T, Sorkness RL, Teague WG: International ERS/ATS guidelines on definition, evaluation and treatment of severe asthma. Eur Respir J 2014, 43:343-373.

2. Wills-Karp M: Immunologic basis of antigen-induced airway hyperresponsiveness. Annu Rev Immunol 1999, 17:255-281.

3. Robinson DS, Hamid Q, Ying S, Tsicopoulos A, Barkans J, Bentley AM, Corrigan C, Durham SR, Kay AB: Predominant TH2-like bronchoalveolar T-lymphocyte population in atopic asthma. N Engl J Med 1992, 326:298-304.

4. Hamid Q, Azzawi M, Ying S, Mogbel R, Wardlaw AJ, Corrigan CJ, Bradley B, Durham SR, Collins JV, Jeffery PK, Quint DJ, Kay AB: Expression of mRNA for interleukin-5 in mucosal bronchial biopsies from asthma. J Clin Invest 1991, 87:1541-1546.

5. Al-Ramli W, Prefontaine D, Chouiali F, Martin JG, Olivenstein R, Lemiere C, Hamid Q: T(H)17-associated cytokines (IL-17A and IL-17 F) in severe asthma. J Allergy Clin Immunol 2009, 123:1185-1187.

6. Molet S, Hamid Q, Davoine F, Nutku E, Taha R, Page N, Olivenstein R, Elias J, Chakir J: IL-17 is increased in asthmatic airways and induces human bronchial fibroblasts to produce cytokines. J Allergy Clin Immunol 2001 108:430-438.

7. Barczyk A, Pierzchala W, Sozanska E: Interleukin-17 in sputum correlates with airway hyperresponsiveness to methacholine. Respir Med 2003, 97:726-733.

8. Van der Pouw Kraan TC, Van der Zee JS, Boeije LC, De Groot ER, Stapel SO, Aarden $\mathrm{LA}$ : The role of $\mathrm{LL}-13$ in $\mathrm{IgE}$ synthesis by allergic asthma patients. Clin Exp Immunol 1998, 111:129-135.

9. Saha SK, Berry MA, Parker D, Siddiqui S, Morgan A, May R, Monk P, Bradding P, Wardlaw AJ, Pavord ID, Brightling CE: Increased sputum and bronchial biopsy IL-13 expression in severe asthma. J Allergy Clin Immunol 2008, 121:685-691.

10. Bullens DM, Truyen E, Coteur L, Dilissen E, Hellings PW, Dupont LJ, Ceuppens JL: IL-17 mRNA in sputum of asthmatic patients: linking T cell driven inflammation and granulocytic influx? Respir Res 2006, 7:135.

11. Vazquez-Tello A, Halwani R, Hamid Q, Al-Muhsen S: Glucocorticoid receptor-beta up-regulation and steroid resistance induction by IL-17 and IL-23 cytokine stimulation in peripheral mononuclear cells. J Clin Immunol 2013, 33:466-478.

12. Laan M, Cui ZH, Hoshino H, Lotvall J, Sjostrand M, Gruenert DC, Skoogh BE, Linden A: Neutrophil recruitment by human IL-17 via C-X-C chemokine release in the airways. $J$ Immunol 1999, 162:2347-2352.

13. Zhao Y, Yang J, Gao YD: Altered expressions of helper T cell (Th)1, Th2, and Th17 cytokines in CD8(+) and gammadelta T cells in patients with allergic asthma. J Asthma 2011, 48:429-436.

14. Zhao Y, Yang J, Gao YD, Guo W: Th17 immunity in patients with allergic asthma. Int Arch Allergy Immunol 2010, 151:297-307.

15. Cosmi L, Maggi L, Santarlasci V, Capone M, Cardilicchia E, Frosali F, Querci V, Angeli R, Matucci A, Fambrini M, Liotta F, Parronchi P, Maggi E, Romagnani $S$, Annunziato F: Identification of a novel subset of human circulating memory CD4(+) T cells that produce both IL-17A and IL-4. J Allergy Clin Immunol 2010, 125:222-230. e221-224.

16. Wenzel SE, Schwartz LB, Langmack EL, Halliday JL, Trudeau JB, Gibbs RL, Chu HW: Evidence that severe asthma can be divided pathologically into two inflammatory subtypes with distinct physiologic and clinical characteristics. Am J Respir Crit Care Med 1999, 160:1001-1008.

17. Fahy JV: Eosinophilic and neutrophilic inflammation in asthma: insights from clinical studies. Proc Am Thorac Soc 2009, 6:256-259.

18. Cohn L, Homer RJ, Marinov A, Rankin J, Bottomly K: Induction of airway mucus production By T helper 2 (Th2) cells: a critical role for interleukin 4 in cell recruitment but not mucus production. J Exp Med 1997, 186:1737-1747.

19. Grunig G, Warnock M, Wakil AE, Venkayya R, Brombacher F, Rennick DM, Sheppard D, Mohrs M, Donaldson DD, Locksley RM, Corry DB: Requirement for IL-13 independently of IL-4 in experimental asthma. Science 1998, 282:2261-2263.

20. Brewer JM, Conacher M, Hunter CA, Mohrs M, Brombacher F, Alexander J: Aluminium hydroxide adjuvant initiates strong antigen-specific Th2 responses in the absence of IL-4- or IL-13-mediated signaling. J Immunol 1999, 163:6448-6454.

21. McKinley L, Alcorn JF, Peterson A, Dupont RB, Kapadia S, Logar A, Henry A, Irvin CG, Piganelli JD, Ray A, Kolls JK: TH17 cells mediate steroid-resistant airway inflammation and airway hyperresponsiveness in mice. J Immunol 2008, 181:4089-4097.

22. Zhao J, Lloyd CM, Noble A: Th17 responses in chronic allergic airway inflammation abrogate regulatory T-cell-mediated tolerance and contribute to airway remodeling. Mucosal Immunol 2012, 6:335-346.

23. He R, Oyoshi MK, Jin H, Geha RS: Epicutaneous antigen exposure induces a Th17 response that drives airway inflammation after inhalation challenge. Proc Natl Acad Sci U S A 2007, 104:15817-15822.

24. Wilson RH, Whitehead GS, Nakano H, Free ME, Kolls JK, Cook DN: Allergic sensitization through the airway primes Th17-dependent neutrophilia and airway hyperresponsiveness. Am J Respir Crit Care Med 2009, 180:720-730.

25. Bogaert P, Naessens T, De Koker S, Hennuy B, Hacha J, Smet M, Cataldo D, Di Valentin E, Piette J, Tournoy KG, Grooten J: Inflammatory signatures for eosinophilic vs. neutrophilic allergic pulmonary inflammation reveal critical regulatory checkpoints. Am J Physiol Lung Cell Mol Physiol 2011, 300:L679-L690.

26. Wakashin H, Hirose K, Maezawa Y, Kagami S, Suto A, Watanabe N, Saito Y, Hatano M, Tokuhisa T, Iwakura Y, Puccetti P, Iwamoto I, Nakajima H: IL-23 
and Th17 cells enhance Th2-cell-mediated eosinophilic airway inflammation in mice. Am J Respir Crit Care Med 2008, 178:1023-1032.

27. Kinyanjui MW, Shan J, Nakada EM, Qureshi ST, Fixman ED: Dose-dependent effects of IL-17 on IL-13-induced airway inflammatory responses and airway hyperresponsiveness. J Immunol 2013, 190:3859-3868.

28. Murdoch JR, Lloyd CM: Resolution of allergic airway inflammation and airway hyperreactivity is mediated by IL-17-producing \{gamma\}\{delta\}T cells. Am J Respir Crit Care Med 2010, 182:464-476.

29. Nakano H, Free ME, Whitehead GS, Maruoka S, Wilson RH, Nakano K, Cook DN: Pulmonary CD103(+) dendritic cells prime Th2 responses to inhaled allergens. Mucosal Immunol 2012, 5:53-65.

30. Livak KJ, Schmittgen TD: Analysis of relative gene expression data using real-time quantitative PCR and the 2(-Delta Delta $C(T))$ Method. Methods 2001, 25:402-408.

31. Lajoie S, Lewkowich IP, Suzuki Y, Clark JR, Sproles AA, Dienger K, Budelsky AL, Wills-Karp M: Complement-mediated regulation of the IL-17A axis is a central genetic determinant of the severity of experimental allergic asthma. Nat Immunol 2010, 11:928-935.

32. Song C, Luo L, Lei Z, Li B, Liang Z, Liu G, Li D, Zhang G, Huang B, Feng ZH: IL-17-producing alveolar macrophages mediate allergic lung inflammation related to asthma. J Immunol 2008, 181:6117-6124

33. Koenecke C, Chennupati V, Schmitz S, Malissen B, Forster R, Prinz I: In vivo application of $\mathrm{mAb}$ directed against the gammadelta TCR does not deplete but generates "invisible" gammadelta T cells. Eur J Immunol 2009, 39:372-379.

34. Conrad ML, Yildirim AO, Sonar SS, Kilic A, Sudowe S, Lunow M, Teich R, Renz H, Garn H: Comparison of adjuvant and adjuvant-free murine experimental asthma models. Clin Exp Allergy 2009, 39:1246-1254.

35. Eisenbarth SC, Colegio OR, O'Connor W, Sutterwala FS, Flavell RA: Crucial role for the Nalp3 inflammasome in the immunostimulatory properties of aluminium adjuvants. Nature 2008, 453:1122-1126.

36. Brewer JM, Conacher M, Satoskar A, Bluethmann H, Alexander J: In interleukin-4-deficient mice, alum not only generates T helper 1 responses equivalent to freund's complete adjuvant, but continues to induce T helper 2 cytokine production. Eur J Immunol 1996, 26:2062-2066

37. Stills HF Jr: Adjuvants and antibody production: dispelling the myths associated with Freund's complete and other adjuvants. ILAR J 2005, 46:280-293.

38. Sutton CE, Lalor SJ, Sweeney CM, Brereton CF, Lavelle EC, Mills KH: Interleukin-1 and IL-23 induce innate IL-17 production from gammadelta T cells, amplifying Th17 responses and autoimmunity. Immunity 2009, 31:331-341.

39. Cohn L, Homer RJ, MacLeod H, Mohrs M, Brombacher F, Bottomly K: Th2-induced airway mucus production is dependent on IL-4Ralpha, but not on eosinophils. J Immunol 1999, 162:6178-6183.

40. Hessel EM, Van Oosterhout AJ, Van Ark I, Van Esch B, Hofman G, Van Loveren H, Savelkoul HF, Nijkamp FP: Development of airway hyperresponsiveness is dependent on interferon-gamma and independent of eosinophil infiltration. Am J Respir Cell Mol Biol 1997, 16:325-334.

41. Ollerenshaw SL, Woolcock AJ: Characteristics of the inflammation in biopsies from large airways of subjects with asthma and subjects with chronic airflow limitation. Am Rev Respir Dis 1992, 145:922-927.

42. Tomkinson A, Cieslewicz G, Duez C, Larson KA, Lee JJ, Gelfand EW: Temporal association between airway hyperresponsiveness and airway eosinophilia in ovalbumin-sensitized mice. Am J Respir Crit Care Med 2001, 163:721-730.

43. Corry DB, Folkesson HG, Warnock ML, Erle DJ, Matthay MA, Wiener-Kronish $J P$, Locksley RM: Interleukin 4, but not interleukin 5 or eosinophils, is required in a murine model of acute airway hyperreactivity. $J$ Exp Med 1996, 183:109-117.

44. Wills-Karp M, Luyimbazi J, Xu X, Schofield B, Neben TY, Karp CL, Donaldson DD: Interleukin-13: central mediator of allergic asthma. Science 1998, 282:2258-2261.

45. Lalor SJ, Dungan LS, Sutton CE, Basdeo SA, Fletcher JM, Mills KH: Caspase-1-processed cytokines IL-1 beta and IL-18 promote IL-17 production by gammadelta and CD4 T cells that mediate autoimmunity. J Immunol 2011, 186:5738-5748.

46. Lockhart E, Green AM, Flynn JL: IL-17 production is dominated by gammadelta T cells rather than CD4 T cells during Mycobacterium tuberculosis infection. J Immunol 2006, 177:4662-4669.
47. Franchi L, Nunez G: The Nlrp3 inflammasome is critical for aluminium hydroxide-mediated IL-1 beta secretion but dispensable for adjuvant activity. Eur J Immunol 2008, 38:2085-2089.

48. Jin N, Taube C, Sharp L, Hahn YS, Yin X, Wands JM, Roark CL, O'Brien RL, Gelfand EW, Born WK: Mismatched antigen prepares gamma delta T cells for suppression of airway hyperresponsiveness. J Immunol 2005, 174:2671-2679.

49. Hahn YS, Taube C, Jin N, Takeda K, Park JW, Wands JM, Aydintug MK, Roark CL, Lahn M, O'Brien RL, Gelfand EW, Born WK: V gamma 4+ gamma delta $T$ cells regulate airway hyperreactivity to methacholine in ovalbumin-sensitized and challenged mice. J Immunol 2003, 171:3170-3178.

50. Faustino L, da Fonseca DM, Takenaka MC, Mirotti L, Florsheim EB, Guereschi MG, Silva JS, Basso AS, Russo M: Regulatory T cells migrate to airways via CCR4 and attenuate the severity of airway allergic inflammation. J Immunol 2013, 190:2614-2621.

51. Sutton CE, Mielke LA, Mills KH: IL-17-producing gammadelta T cells and innate lymphoid cells. Eur J Immunol 2012, 42:2221-2231.

52. Roark CL, Huang Y, Jin N, Aydintug MK, Casper T, Sun D, Born WK, O'Brien RL: A canonical Vgamma4Vdelta4+ gammadelta T cell population with distinct stimulation requirements which promotes the Th17 response. Immunol Res 2013, 55:217-230.

53. Oboki K, Ohno T, Saito H, Nakae S: Th17 and allergy. Allergol Int 2008, 57:121-134.

54. Pollinger B, Junt T, Metzler B, Walker UA, Tyndall A, Allard C, Bay S, Keller R, Raulf F, Di Padova F, O'Reilly T, Horwood NJ, Patel DD, Littlewood-Evans A: Th17 cells, not IL-17+ gammadelta T cells, drive arthritic bone destruction in mice and humans. J Immunol 2011, 186:2602-2612.

\section{doi:10.1186/s12931-014-0090-5}

Cite this article as: Nakada et al.: Adjuvant-dependent regulation of interleukin-17 expressing $\gamma \delta \mathrm{T}$ cells and inhibition of Th2 responses in allergic airways disease. Respiratory Research 2014 15:90.

\section{Submit your next manuscript to BioMed Central and take full advantage of:}

- Convenient online submission

- Thorough peer review

- No space constraints or color figure charges

- Immediate publication on acceptance

- Inclusion in PubMed, CAS, Scopus and Google Scholar

- Research which is freely available for redistribution 